\title{
When I was your age
}

\section{The more things change...}

\section{John E. Stith}

$\mathrm{R}$ alph slouched against the bed, twisting sections of an antique Rubik's Cube and finding chaos increasing. On the other side of the room, his friend, Terry, sat cross-legged, tossing his baseball into the air and catching it. The window behind him revealed moonlit rooftop spires in Bombay.

"Well?" Ralph asked.

"The parties at Plato's are boring. And you don't even know if you can borrow the scooter."

"I can deal with Dad."

"He's probably still mad about the time you slipped that concoction into your kid brother's food and he lost all his hair."

"It grew back, for Pete's sake. Try me," Ralph said. "You be him."

Terry stopped tossing, twisted to face him. He squared his shoulders, getting into the role. "All right, young man," he said with a deepened voice. "Tell me why I should say yes."

"Mom said it was okay with her if it was okay with you."

"She didn't tell me that. Maybe I should ask her in here."

"This is important, Dad. You say social skills are as vital to getting ahead as what you study. This party lets me develop my social skills."

Terry frowned and said: "When I was your age, we only had ten elements, and most of them were gases."
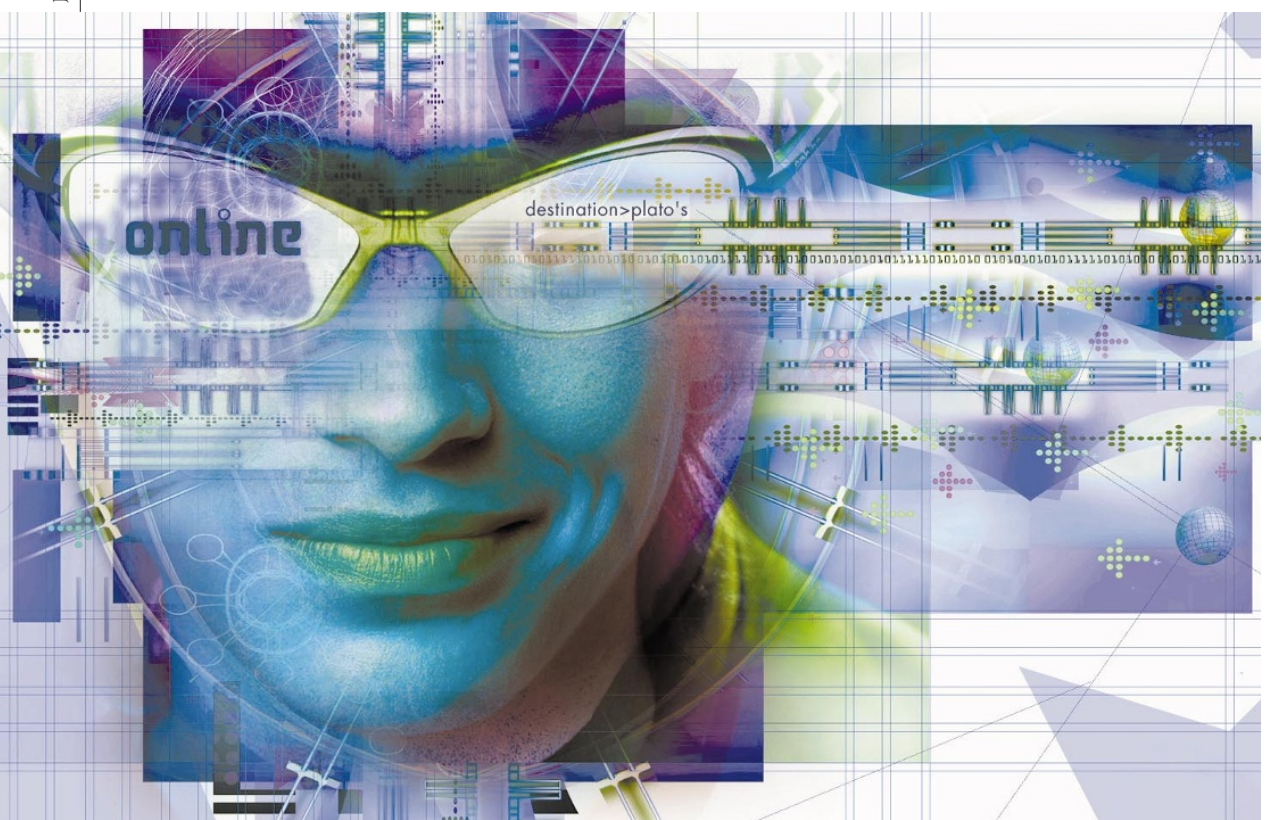

face him. "All right, young man. Tell me why I should say yes."

So predictable. "Mom said —-"

"By the way. I got a call from Mr Hammond at school. Bioengineering class."

"Dad, I can explain —-"

"So a virus you created in lab somehow got loose. And it turned everyone's skin blue."

"Well, not everyone's —-"

"Oh, right. Somehow you miraculously avoided infection."

"The thing to keep in mind here, Dad, is that everyone is back to normal. It's not like anyone died." Ralph knew this vein wasn't nearing the mother lode.

"When I was your age, I only got to use the family scooter once a month."

"I know, and Gramps could only afford to take it to the end of the block."

"Now don't get smart with -

"Sorry, Dad. It's just that times change, you know?"

"I still don't see why you need to go to this party."

"You always say how valuable social skills are. This is - " Ralph followed Dad's gaze. Mom was standing in the doorway.

"Mom," Ralph said, "I was just talking to Dad about going to a party. He said that might give you some quality time together tonight."

Ralph could see Dad readying a contradiction, but Mom beat him to the punch with a smile not quite like her normal smile. "Is that so, Honey?" Mom said.

Dad got kind of a dopey smile, too. "If that works for you, Dear."

Checkmate.

Mom just smiled some more. Dad distractedly handed the key-card to Ralph. "Be back by one." He glanced at Mom. "No, make that two."

"Anything you say."

In the scooter, Ralph settled into the deeply cushioned seat. "Autopilot. Plato's, and step on it."

The garage roof slid aside and the scooter rose silently. Once safely over the New Jersey neighbourhood, the craft pitched and yawed into the right attitude, and the gees piled on, pressing Ralph deep into the cushions. The autopilot said, "ETA Plato Crater Spaceport, Luna, twenty hundred hours."

The air outside faded from blue towards black.

Parents were just so old fashioned. He was really going to have to work on them for prom week on Ganymede.

Nebula Award-nominated John E. Stith

(www.neverend.com) is the author of Redshift Rendezvous, Manhattan Transfer, and others. 